\title{
The impact of emotional intelligence on behavioural factors during transition: A case of the Free State Technical and Vocational Education and Training colleges
}

\begin{tabular}{|c|c|}
\hline \multicolumn{2}{|c|}{$\begin{array}{l}\text { Authors: } \\
\text { Sarone D. Motlhanke } \\
\text { Matsidiso N. Naong }{ }^{1} \text { (D) }\end{array}$} \\
\hline \multicolumn{2}{|c|}{$\begin{array}{l}\text { Affiliations: } \\
\text { }{ }^{1} \text { Department of Business } \\
\text { Management, Faculty of } \\
\text { Management Sciences, } \\
\text { Central University of } \\
\text { Technology, Bloemfontein, } \\
\text { South Africa }\end{array}$} \\
\hline \multicolumn{2}{|c|}{$\begin{array}{l}\text { Corresponding author: } \\
\text { Matsidiso Naong, } \\
\text { mnaong@cut.ac.za }\end{array}$} \\
\hline \multicolumn{2}{|c|}{$\begin{array}{l}\text { Dates: } \\
\text { Received: } 20 \text { Apr. } 2021 \\
\text { Accepted: } 18 \text { Sept. } 2021 \\
\text { Published: } 13 \text { Dec. } 2021\end{array}$} \\
\hline \multicolumn{2}{|c|}{$\begin{array}{l}\text { How to cite this article: } \\
\text { Motlhanke, S.D., \& Naong, } \\
\text { M.N. (2021). The impact of } \\
\text { emotional intelligence on } \\
\text { behavioural factors during } \\
\text { transition: A case of the Free } \\
\text { State Technical and } \\
\text { Vocational Education and } \\
\text { Training colleges. SA Journal } \\
\text { of Human Resource } \\
\text { Management/SA Tydskrif vir } \\
\text { Menslikehulpbronbestuur, } \\
\text { 19(0), a1641. https://doi. } \\
\text { org/10.4102/sajhrm. } \\
\text { v19i0.1641 }\end{array}$} \\
\hline \multicolumn{2}{|c|}{$\begin{array}{l}\text { Copyright: } \\
\text { (C) 2021. The Authors } \\
\text { Licensee: AOSIS. This } \\
\text { is licensed under the } \\
\text { Creative Commons } \\
\text { Attribution License. }\end{array}$} \\
\hline \multicolumn{2}{|l|}{ Read online: } \\
\hline 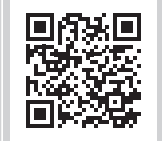 & $\begin{array}{l}\text { Scan this QR } \\
\text { code with your } \\
\text { smart phone or } \\
\text { mobile device } \\
\text { to read online. }\end{array}$ \\
\hline
\end{tabular}

Orientation: Numerous changes at the Technical and Vocational Education and Training (TVET) requires some degree of emotional intelligence (EI) to achieve any level of efficiency, competitiveness and success.

Research purpose: The primary purpose of this research is to empirically contribute to a comprehension of how a leader's EI can be utilised to positively influence organisational behaviours during the transitional period.

Design/methodology/approach: The study adopted a positivist research approach, that is descriptive in nature. A survey was conducted by providing a structured questionnaire to a sample of 310 academics and support staff of the TVET college sector in the Free State Province of South Africa. Data analysis was based on a total of 188 questionnaires collected, giving a return rate of $61 \%$. The structural equation modelling (SEM) analysis and interpretation was conducted using a component-based approach to establish the correlation between the items.

Main Findings: The SEM findings revealed that EI of Free State TVET college managers significantly affects all the dependent variables namely, organisational work commitment, employee job satisfaction, task-oriented behaviour, teamwork except staff morale. Emotional intelligence reflects a reasonable power of predictability toward all other variables except staff morale of the respondents.

Practical/managerial implications: To ensure sustained exceptional performance, recruitment strategy for managers must deliberately incorporate EI measurements at TVET colleges.

Contribution/value add: The study demonstrates empirical proof of the positive impact of a leader's EI on organisational behaviours, thereby confirming that EI is an enabler of organisational work commitment, job satisfaction, task-oriented behaviour, teamwork, but not staff morale.

Keywords: emotional intelligence; job satisfaction; task-oriented behaviour; teamwork; staff morale; Technical and Vocational Education and Training.

\section{Introduction}

Organisations strive to maximise profit. However, they comprehend that efficiency and productivity are a pipe dream if the heads, hearts and hands of every staff member are not on deck. To realise this goal, leaders and managers are critical for motivation and inspiration of the subordinates. Russell (2020) asserted that with the current crisis of COVID-19 pandemic, leaders are being closely observed and are required to take correct decisions and exhibit appropriate behaviours, which include showing humility (i.e. putting others first) and empathy. It is generally agreed that because emotional intelligence (EI) prescribes the nature of interaction within teams, leaders with a high EI exhibit social expertise and empathy, and can readily gauge the emotional environment in which they are working. That said, high staff morale or work motivation is a function of a leader's EI. Because workers need adequately equipped leaders not only to lead change but also meaningfully influence followers towards accomplishment of organisational goals. Numerous studies (Gabcanova, 2011; Naong, 2014) have attested to the value of this important asset, that is, workers. A manager or leader's influence, empathy and inspiration collectively act as a catalyst for getting the best out of each employee.

Leaders' emotional status impacts that of their employees. Thus, a positive attitude encourages enthusiasm and enables information sharing thereby leading to outstanding performance. 
Conversely, negative emotions on the part of the leader cause anxiety, anger and detachment, all of which impede the team's success (Wisse, Rus, Keller, \& Sleebos, 2019). Previous researches have indicated that emotionally intelligent leaders instil confidence in their team employees by counteracting contradictory situations, thus, ensuring they are encircled in positive emotions (Affum-osei, Acquaah, \& Acheampong, 2015; Vasudevan \& Mahadi, 2017). Hence, a leader with high EI understands how emotions impact their employees' attitudes and needs, and consequently, facilitates a constructive psychological climate (Owolabi, 2012). Gupta and Bajaj (2017) likewise proposed that a leader's EI affects employees' opinion of the working environment. In this article, the effects of a leader's EI on selected work behaviours of academics and support staff across the Technical and Vocational Education \& Training (TVET) sector in the Free State Province of South Africa are explored.

\section{Impact of transformational trajectory of the Technical and Vocational Education and Training sector}

The TVET sector has been earmarked as a critical role-player within the South African economy, having changed from the manpower pre-democratic dispensation to Further Education and Training (FET), and ultimately, TVET post-democratic era. Its recent elevation from Basic Education to the Higher Education (HE) sector inspired hope, but equally instilled trepidation of its core mandate being diluted and muddled with those of the HE sector. Leadership change and illprepared students, with lack of commitment and work ethic drain staff's energies as their efforts amounted to zero. A mandate of providing trade skills and technical education to drive the South African economy has never been so critically necessitous and ominous, with unemployment rate escalating at an alarming rate. Industrious bemoan a perennial mismatch between their expectations and the readiness level of HE graduates to join the world of work. Practical hands-on experience and skills underpin the mandate of the TVET sector of engendering a culture of job creators instead of job seekers. Contrary to other countries such as Germany, Singapore, Zimbabwe, and Thailand, the South African TVET sector is yet to command and pass an 'appeal test' amongst young people and make a much-needed impact on the socioeconomic imperatives of the South African society. This pervasive state of affairs adversely affects the TVET workforce. This can only be ameliorated by a determined leadership to avoid uncertainty, despondency and chaos. It shows that every leader's task is becoming ever more critical in directing and influencing the behaviour of their subordinates towards this crucial goal. Foltin and Keller (2012) overtly asserted that inevitably change impelled by leaders tends to occur within organisational environment characterised by chaos, ambiguities and emotional reactions to change.

Issah (2018) posited that 21st century leaders bear the major responsibility for leading their organisations towards successful change. However, change evokes disparate sentiments because people value the security of retaining the status quo and established norms. Thus, leaders will have to overcome these challenges. Moore (2009) believed that only leaders who possess appropriate EI leadership behaviour will be able to promote effective organisational change. Additionally, much documentary evidence continues to point out that leadership requires some degree of EI to achieve any level of success (Gupta \& Bajaj, 2017; Ngirande \& Timothy, 2014). Similarly, Abdollah et al. (2016) opined that psychological qualities such as a leader's EI is considered to be an integral part of the competitiveness and success of any organisation. Nordin (2011) added that the change process is boosted when employees experience emotional security within their organisation.

In examining the appropriateness of one's leadership style and its impact, it is imperative to ask yourself whether your employees are motivated and engaged, or are they demotivated and disengaged. It is generally accepted that the higher the level of leadership, the greater the number of employees impacted. Thus, the extent of these leaders' EI becomes progressively imperative. The top executive governs the organisation's ambiance which embraces its emotional status and perceived organisational climate. Hence, leaders exhibiting poor EI decrease employee morale and leads to high staff turnover (Qureshi, Ali, Raza, \& Whitty, 2013). Frequently, one of the main reasons employees give for leaving an organisation is their relationship with the management. It is essential for leaders to ensure effective communication and collaboration within their organisations because employees' welfare is the essence of success. Emotional intelligence is generally accepted and regarded as a significant leadership aptitude for ensuring effective interaction between management and employees in a variety of situations (Vasudevan \& Mahadi, 2017). Contented employees are motivated and thus become loyal employees who ensure that their company remains competitive (Gabcanova, 2011).

\section{Purpose and problem statement}

The TVET sector underwent many changes in the recent past, which resulted in daunting demands and challenges on the resources and the staff. New management and the COVID-19 crisis are further compounding the situation, with instant expectations for the staff to master virtual or digital teaching and learning approaches overnight. This causes a demanding re-engineering and paradigm shift on both the management and the staff to stay energised and motivated to optimally and efficiently achieve organisational mission and goals. Generally, the pervasive culture of 'them and us' arguably still mirrors the current status quo at various TVET colleges under study and characterise the type of relations between college leaders and subordinates, hence this study.

\section{Literature review}

Emotional intelligence and its dimensions: According to Qureshi et al. (2013), Salovey and Mayer (1990) initially introduced the term EI and described it as 'a form of acumen 
TABLE 1: Components of emotional intelligence.

\begin{tabular}{lll}
\hline Component & Definition & Elements \\
$\begin{array}{l}\text { Self- } \\
\text { awareness }\end{array}$ & $\begin{array}{l}\text { Ability to understand one's moods, } \\
\text { emotions, and drives as well as its effect } \\
\text { on others }\end{array}$ & $\begin{array}{l}\text { Self-confidence; } \\
\text { Realistic self-assessment; } \\
\text { Self-deprecating sense of } \\
\text { humour }\end{array}$ \\
$\begin{array}{l}\text { Self- } \\
\text { regulation }\end{array}$ & $\begin{array}{l}\text { Ability to control or redirect disruptive } \\
\text { impulses or moods; } \\
\text { Propensities to suspend judgement, } \\
\text { think before acting }\end{array}$ & $\begin{array}{l}\text { Trustworthiness and integrity; } \\
\text { Comfort with ambiguity; } \\
\text { Openness to change }\end{array}$ \\
$\begin{array}{l}\text { Self- } \\
\text { motivation }\end{array}$ & $\begin{array}{l}\text { Passion to work for reasons beyond } \\
\text { money or status; } \\
\text { Propensity to pursue goals with energy } \\
\text { and persistence }\end{array}$ & $\begin{array}{l}\text { Strong drive to achieve } \\
\text { optimism, even in the face of } \\
\text { failure; Organisational } \\
\text { commitment }\end{array}$ \\
Empathy & $\begin{array}{l}\text { Ability to understand the emotional } \\
\text { makeup of other people; } \\
\text { Skill in treating people according to their } \\
\text { emotional reactions }\end{array}$ & $\begin{array}{l}\text { Expertise in building and } \\
\text { retaining talent; } \\
\text { Cross-cultural sensitivity; }\end{array}$ \\
Service to clients
\end{tabular}

Source: Goleman, D. (2001). Emotional intelligence: Issues in paradigm building. In C Cherniss \& D. Goleman (eds.), The emotionally intelligent workplace. How to select for, measure and improve emotional intelligence in individuals, groups and organizations (pp. 13-26). San Francisco, CA: Jossey-Bass.

comprising the capability to comprehend and observe one's personal and others' sentiments and employing this knowhow to inform personal decision making and behaviours. Other writers deemed that EI also encompasses characteristics including amongst others forcefulness, impetuosity and buoyancy (Goleman, 1995; Mayer \& Salovey, 1997; Petrides \& Furnham, 2001; Schutte et al., 1998).

A myriad of research studies reported that EI is ingrained in the aptitude measuring movement. For example, Sariolghalam, Noruzi and Rahimi (2010) acknowledged the multiplicity of intelligences importantly social intelligence amongst many of them. However, measuring social intelligence has always been considered difficult.

Job satisfaction: Situational theories assume that job satisfaction depends upon the interaction of variables such as:task-, organisational- and individual characteristics (Asad-urRehman, Ullah, \& Abrar-ul-haq, 2015; Hanafi, 2016; Rahman \& Haleem, 2018). Documentary evidence continues to show job satisfaction as a significant variable with regard to employee's performance together with the predictors of work behaviour (Bakotić, 2016; Latif et al., 2015; Mafini \& Pooe, 2013). Job satisfaction improves workers' morale and time-keeping, whilst simultaneously, decreasing their complaints, grievances, absenteeism and the cost of training new employees, thus, resulting in higher turnover for organisations (Hira \& Waqas, 2012). Equally, this employee motivation further hinges on leadership style, the reward system, the organisational climate and the structure of the work, amongst others. Most importantly, any leadership change within an organisation is likely to alter the company's psychological climate and consequently improves employees performance. Flowing from this discussion, this hypothesis is then necessitated, where it is opined that a positive correlation exists between leader's EI and job satisfaction (Khanzada, Naeem, \& Butt, 2018; Rahman \& Haleem, 2018; Yusoff, Muda, \& Ishak, 2016).

Change, leadership and emotional intelligence: Any situational change predicated on the smouldering desire for organisational success, hinges on the ability and intelligence of the leader to communicate, secure and manage the buy-in of all members within the organisation for the need to change. Lazenby (2018) identified 'dissatisfaction with the status quo', amongst many other change causes, and therefore the leader's adeptness at disseminating the need for transforming the status quo will govern the organisational acceptance of this proposal. In cases in which employees are content with the current situation and resist change, effective leadership communication is needed to generate dissatisfaction with the status quo (Gaubatz \& Ensminger, 2017). The change process initially induces fear and anxiety amongst employees thus necessitating persuasive communication by leaders (Foltin \& Keller, 2012). Leaders with high EI create an environment of interaction so that employees subject to change can help to analyse the organisation's current scenario and formulate its future desired state (Foltin \& Keller, 2012; Issah \& Zimmerman, 2016). That said, the role of effective and intelligent leadership remains key for any organisational change to succeed. Consequently, this makes EI a vital ingredient to boost staff morale, promote cooperation, foster teamwork, increase motivation, and enhance a positive and healthy work environment (Rahman \& Haleem, 2018; Strickland, 2000 in Foltin \& Keller, 2012, p. 22).

Emotional intelligence and commitment: Commitment is defined as a force that commits people to following the relevant procedure necessary for achieving specific targets (Alrowwad, Almajali, Masa'deh, Obeidat, \& Aqqad, 2019; Singh \& Gupta, 2015). Similarly, PSUWC (2014) defined the organisational commitment as the relative strength of an individual's identification with and involvement in an organisation'. If there is enough inspiration, motivation and sense of belonging, the management can be assured of loyalty, performance and retention. That said, for any organisation aspiring to successfully compete on a global stage, committed and inspired workforce is critical (Naong, 2014) that must be smartly and intelligently managed, because organisational commitment is a desirable organisational outcome (Rahman \& Haleem, 2018). Employee commitment is undoubtedly an outcome of employee job satisfaction and prevailing organisational climate. This prompts us to hypothesise that there is a significant correlation between leaders' EI and employees' institutional commitment.

Teamwork: A cliché 'two heads are better than one' impresses upon every manager to comprehend and appreciate the significance of teamwork within organisations. Teams are the mainstay of businesses and can generate more effective solutions to problems than individuals (Tabassi, Ramli, \& Abu Bakar, 2011). Teamwork forms a significant part of any organisation (Berber, Slavi, \& Aleksi, 2020). It is regarded as functions performed collectively by individual members towards common team goal, for example, team effectiveness and satisfaction (Driskell, Sala, \& Driskell, 2018). Good leaders realise that encouraging effective teamwork create synergy within work teams. Such teams minimise process loss and maximise process gain by engendering high levels 
of cooperation amongst colleagues and motivating both themselves and their teammates to volunteer for tasks outside of their job descriptions (Yang, 2016) Effective leaders play a vital role in inspiring such practices. Given this reality, it is safe to hypothesise that there is a positive correlation between a leader's EI and the teamwork.

Emotional intelligence and staff morale: Myeni (2010) defined morale as all psychological factors and forces that influences the performance of an individual or group especially within the workplace. Tiwari (2014) maintained that this psychological state encourages contentment, confidence and determination amongst staff, leading to motivation, commitment, discipline and degree of fulfilment through innate characteristics like variability, challenges, opportunity for input and growth in the workplace, together with such extrinsic circumstances as adequate earnings, job security, health and safety. Staff morale is an elusive construct connected to the level of contentment and congruent group demeanour towards its company, a state that depends upon concepts such as trust, self-worth, faith in the organisation's management and success, and hinges upon the optimism of each individual group member (Ngambi, 2011). According to Lee, Scheunemann, Hall and Payne (2012), intrinsic motivation, job satisfaction, teamwork and organisational loyalty help to determine staff morale. These definitions expose the dual nature of staff morale, namely, the psychological aspects (employee attitudes and values) and performance facets (employee productivity) which results in causal relationship between these dimensions with the assumption that employees' EI directly impacts their work performance (Myeni, 2010).

Marked inspiration and drive is indicative of employee contentment, consequently, presenting industriousness, enterprising, and commitment towards achieving organisational success rather than personal goals (Tiwari, 2014), and further points out that high morale means satisfied employees whilst low morale equates with discontented employees. Staff morale comprises a mixture of related factors and is affected by many situations like distrust of management, ineffective interpersonal communication between management and staff, static working conditions, unclear expectations, limited prospects for personal growth because of undemanding environments, but the major cause is poor leadership (Lee et al., 2012). Ngambi (2011) posited further reasons such as: lack of leadership role models, accountability and opportunities for career progression. This situation results in the hypothesis that there is indeed a significant correlation between leaders' EI and staff morale.

Relationship between emotional intelligence and employee performance: Emotional intelligence continues to be associated with a myriad of significant organisational outcomes and remains a topical issue as it relates and impact on performance (Khanzada et al., 2018; Owoseni, 2014; Treputtharat \& Tayiam, 2014; Usop, Askandar, Kadtong, \& Usop, 2013; Yukl, 2010). Emotional intelligence in the workplace positively affects employees' morale in terms of their performance, occupational stress, and subsequently, retention. The organisational benefits of EI are increased sales and profit (Khalili, 2012). The results of pre- and post-tests measuring the effect of EI training at universities, indicated a marked increase in students' EI (Ashkanasy, 2001; Clark, Callister, \& Wallace, 2002).

A study by Cook (2006) found that leaders with a higher EI tends to outshine those counterparts with lower EI in terms of their organisational performance. Other reputable studies have associated EI with success in job-related cognitive ability tasks (Kwateng et al., 2014; Wijekoon et al., 2017). The greatest evidence to date regarding the examination of leaders' EI as a means of predicting on-the-job success is reported by Cavallo and Brienza (2002) in their study of the leadership behaviour, found that leaders with high EI were favourably rated by their supervisors, colleagues and subordinates. Furthermore, Owoseni (2014) posited that the Emotional Competency Profiler (ECP) entities that most accurately predicated success were self-confidence, initiative, leadership influence and facilitating change. It is for this reason we hypothesise an affirmative relationship between leaders' EI and task-oriented behaviours.

This analysis is therefore intended to evaluate the structural relationships of these variables as indicated in the conceptual model in Figure 1.

The hypotheses as depicted in the research model were stated as follows:

- H1: There is a positive relationship between leader's EI and organisational commitment.

- H2: There is a positive relationship between leader's EI and employee's job satisfaction.

- H3: There is a positive relationship between leader's EI and task-oriented behaviour.

- H4: There is a positive relationship between leader's EI and teamwork.

- H5: There is a positive relationship between leader's EI and staff morale.

The behaviour and style of leadership is likely to determine the level of motivation, commitment, morale and the performance of their subordinates. Emotional intelligence is a key to unlock this secret and, thus is of value to organisations

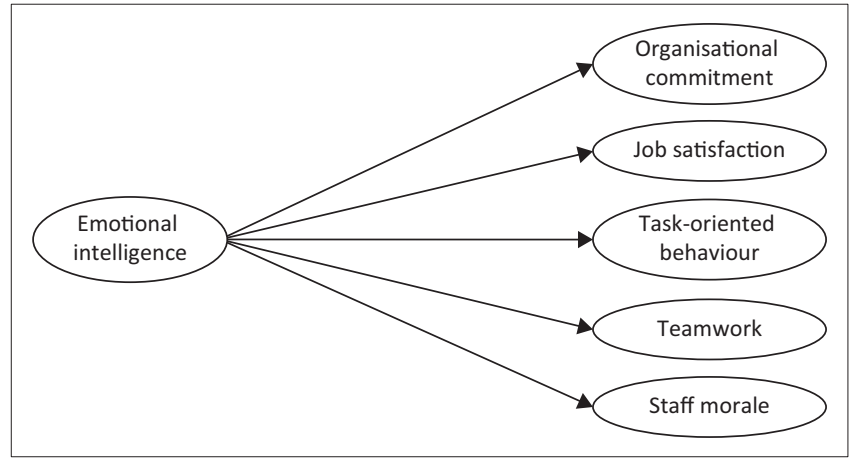

FIGURE 1: Conceptual model. 
because it provides the basis for creating and monitoring employees' emotionally-based soft skills. This research strives to both eradicate possible hindrances to sound interpersonal relations, as well as to promote the consciousness of leaders' EI and an ideal leadership style that can enhance traits such as collegiality, engagement and performance. It is also expected that this study will significantly inform Human Resource Management policies and practices for improving employer/employee relations across the TVET sector in South Africa, and globally.

\section{Theoretical background}

Although a plethora of leadership theories are documented, in this article the two complementary leadership theories that we chose to anchor this study are : the leader and member exchange (LMX) theory by Dansereau, Graen and Haga (1975) as well as the EI theory premised on the seminal work by Salovey and Mayer (1990) on EI. The LMX theory is generally understood to be a leadership approach focused on a twoway (dyadic) relationship between supervisors and subordinates. A primary emphasis of the LMX theory is an understanding of the connection between supervisor and employee, together with the exchanges that occur between them (Monahan, 2013). Poor relationships which are mainly related to employment contracts signify a mistrust, absence of respect and accountability between leaders and subordinates, whilst high quality relationships extend beyond formal work-related matters pertaining to the attainment of organisational goals (Ahmed, 2019). Previous research, such as meta-analysis, indicates that partners in high quality relationships exhibit high performance, professional organisational behaviour and job satisfaction (Constance, Iris, \& Colleen, 2011; Vidyarthi, Liden, Anand, Erdogan, \& Ghosh, 2010). The EI theory encapsulates leaders' capacity to effectively recognise, process and regulate both their own and other's EI and to allow such knowledge to guide their decisions and actions for the benefit of others.

\section{Methodology \\ Research design and sampling size}

This article adopted a quantitative research approach, employing a survey which is descriptive in nature. With a cross-sectional as the most appropriate research design, Creswell (2014) viewed the random sampling technique as one of the best ways to enhance reliability. This is a suitable sampling technique because it affords every participant equal opportunity to be part of the study (Leedy \& Ormond, 2010). Hence, a choice of probability sampling technique was deemed appropriate in this article.

\section{Population and sampling technique}

A population included all four TVET college staff members equalling just over 968 in total, divided between teaching (439) and non-teaching (529) staff from these colleges spanning four regions of one Province of South Africa. Stratified random sampling was employed to draw participants from all management levels of these colleges. Data from the HR divisions of these colleges on organisational structure made stratified sampling possible. A sample of 310 was secured, which is slightly more than what is acceptable from the population between 1,000 and 1,300, which is supposed to be 297 (Sekaran, 2003) at a confidence level of $95 \%$. With a total of 188 fully completed questionnaires collected, a response (return) rate of $61 \%$ was achieved.

\section{Instrumentation and data collection}

The instrument used for data collection comprised a Likert rating scale consisting of 'strongly agree $=5$ to strongly disagree $=1^{\prime}$. Made up of demographic section (including gender, age, race, education level, work experience, and title/position) and attitudinal factors regarding EI Inventory developed by Goleman, Boyatzis and McKee (2002). Job satisfaction based on Job Descriptive Index (JDI) by Smith, Kendall and Hulin (1969) included items such as 'My superior let me know how well they think I am doing'. For team-work behaviour based on Salas, Sims and Burke (2005) items included were such as 'in our team, our leader ensures that we work as one solid family unit, inspires and support each other'. Performance/task-oriented adapted from Northhouse (2009), included items such as 'our leader maintains consistency of behaviour in ethical and jobrelated matters'. As for staff morale by Milligan, Kendrick and Avan (2004), items included were such as 'my leader/ supervisor always inspires/motivates us to perform better'.

\section{Ethical considerations}

A self-developed measuring instrument was used and four research assistants were dispatched at the four regional colleges of the TVET sector in the province of the Free State for the purpose of ensuring clarity for respondents during the data collection process. After permission was granted by each college management, consultation with the participants ensued. Consent, anonymity and confidentiality of the participants' information and that of their colleges were guaranteed in the cover letter.

\section{Data analysis}

The structural equation modelling (SEM) analysis was conducted using a component-based approach. This approach was adequate given the small sample size. Smart PLS.3 was the package used to conduct the analysis. Structural equation modelling represents a flexible and comprehensive methodology for representing, estimating, and testing a theoretical model with the objective of explaining as much of their variance as possible (Ramlall, 2017). The SEM methodology includes the confirmatory factor analysis (CFA) as well as the structural model analysis. A CFA assesses the validity of the measurements, whilst the structural model analysis tests the research hypotheses specified in the conceptual model (see Figure 1). Brown (2015) stated that CFA is the phase of the SEM that incorporates measurement and includes the interaction 
between observed measures/indicators and latent variables/ constructs. The CFA incorporates analyses of constructs such as reliability, convergent and discriminant validity, each of which are examined and reported in the latter sections of the study.

\section{Statistical data}

This part outlines and presents the statistical results of this article. It provides details of the demographics results of the respondents and other descriptive statistics.

\section{Demographic information}

This section contains a concise demographic information of the participants as well as the development of the SEM. The respondents' profile consisted of $62 \%$ males and $38 \%$ females, with most (35\%) of the participants being between 41 and 50 years of age, followed by 31-40 years (33\%). Africans were in the majority, that is, $96 \%$. Most (45\%) of the participants had a degree, $34 \%$ had a diploma, $15 \%$ had a certificate or matric, whilst those without matric represented a $7 \%$. The majority of respondents occupied positions within a lower management level (44\%). Academics represented 27\% whilst support staff were at $15 \%$. About $49 \%$ had a work experience between 1 and 5 , followed by those between 6 and 15 years at $31 \%$.

\section{Determining reliability and convergent validity}

Reliability refers to the degree to which the results / quality of a measurement of a phenomenon is being trustworthy or of performing well consistently (Taherdoost, 2016). Cronbach's alpha and Composite Reliability (CR) are generally used to assess the scale's reliability in SEM analyses (Field, 2013). Although the required cut-off value of both the Cronbach's alpha and CR is 0.7 , a value of 0.6 is sometimes permissible (Malhothra et al., 2017) too. Results in Table 2 show that the CR ranges from 0.641 to 0.896 , thus indicating an overall acceptable level of internal consistency of all six constructs considered in the model. Based on this result, all constructs are considered reliable.

\section{Convergent validity}

Convergent validity refers to 'the extent to which a set of items only measure one latent variable in the same direction' (Hosany et al., 2015). According to the results presented in Table 2, statistical evidence supports the convergent validity of all the measurements except the construct EI which has an Average Variance Extracted $(\mathrm{AVE}=0.311)$ lower than the recommended threshold of 0.5. Note that the items EPOC2, EPOC3, EI1, EI3 and EI6 were deleted because of low factor loading.

The results as indicated in Table 2, statistically support the reliability and the convergent validity of the items retained in the final model except the items of the construct EI. In overall, most of the items retained in the final measurement model are good measures of their respective constructs. The statistical evidence of discriminant validity is presented and discussed next using Fornell and Larcker (1981) approach (See Table 3).

\begin{tabular}{|c|c|c|c|c|c|c|c|}
\hline Constructs & Items & Factor loadings & $P$-value & Cronbach's alpha & Composite reliability & $\begin{array}{c}\text { Average variance } \\
\text { extracted (AVE) }\end{array}$ & $\begin{array}{l}\text { Final number of items } \\
\text { and (initials) }\end{array}$ \\
\hline \multirow{3}{*}{$\begin{array}{l}\text { Employee's perceived } \\
\text { organisational commitment }\end{array}$} & EPOC1 & 0.529 & $* * *$ & 0.606 & 0.751 & 0.514 & $3(5)$ \\
\hline & EPOC4 & 0.651 & $* * *$ & & & & \\
\hline & EPOC5 & 0.915 & $* * *$ & & & & \\
\hline \multirow[t]{5}{*}{ Employees job satisfaction } & EJS1 & 0.815 & $* * *$ & 0.843 & 0.876 & 0.586 & $5(5)$ \\
\hline & EJS2 & 0.810 & $* * *$ & & & & \\
\hline & EJS3 & 0.744 & $* * *$ & & & & \\
\hline & EJS4 & 0.745 & $* * *$ & & & & \\
\hline & EJS5 & 0.707 & $* * *$ & & & & \\
\hline \multirow[t]{5}{*}{ Fostering task-oriented behaviour } & FTOB1 & 0.807 & $* * *$ & 0.858 & 0.896 & 0.633 & $5(5)$ \\
\hline & FTOB2 & 0.665 & $* * *$ & & & & \\
\hline & FTOB3 & 0.801 & $* * *$ & & & & \\
\hline & FTOB4 & 0.834 & $* * *$ & & & & \\
\hline & FTOB5 & 0.858 & $* * *$ & & & & \\
\hline \multirow[t]{5}{*}{ Enhancement of teamwork } & ETW1 & 0.887 & $* * *$ & 0.838 & 0.884 & 0.611 & $5(5)$ \\
\hline & ETW2 & 0.701 & $* * *$ & & & & \\
\hline & ETW3 & 0.855 & $* * *$ & & & & \\
\hline & ETW4 & 0.864 & $* * *$ & & & & \\
\hline & ETW5 & 0.546 & $* * *$ & & & & \\
\hline \multirow[t]{5}{*}{ Staff morale } & SM1 & 0.857 & $* * *$ & 0.887 & 0.875 & 0.585 & $5(5)$ \\
\hline & SM2 & 0.825 & $* * *$ & & & & \\
\hline & SM3 & 0.718 & $* * *$ & & & & \\
\hline & SM4 & 0.716 & $* * *$ & & & & \\
\hline & SM5 & 0.696 & $* * *$ & & & & \\
\hline \multirow[t]{4}{*}{ Emotional intelligence } & EI2 & 0.485 & $* * *$ & 0.316 & 0.641 & 0.311 & $4(7)$ \\
\hline & EI4R & 0.525 & $* * *$ & & & & \\
\hline & EI5R & 0.663 & $* * *$ & & & & \\
\hline & EI7 & 0.543 & $* * *$ & & & & \\
\hline
\end{tabular}

***Indicates the significance of the factor at $99 \%$ confidence interval. 


\section{Statistical evidence of discriminant validity}

Discriminant validity refers to the degree to which a latent variable or item discriminates from another latent variables (Taherdoost, 2016). The square root of the AVE is expected to be above the inter-construct correlation coefficients. In this study, discriminant validity was gauged through a comparison of the association amongst a set/group of variables with the square root of AVE of individual items (Malhothra et al., 2017). Correlations greater than the square root of AVE indicate low discriminant validity between the constructs. The results from Table 3 suggest non-discriminant validity amongst the variables because all AVE square roots are above their respective inter-construct correlation values.

\section{Structural model analysis}

This part submits and covers the structural model analysis of statistical results. In terms of the results, the empirical model explains: $7.6 \%\left(R^{2}\right)$ of the variance of organisational commitment, $5.1 \%$ of job satisfaction, $3.8 \%$ of task-oriented behaviour, $4.8 \%$ of enhancement teamwork, and $2.7 \%\left(R^{2}\right)$ of the variance of staff morale (see Figure 2).

Table 4 establishes the predictive influence of the independent item on dependent items. The Beta values indicate the direction and the power of the correlation, whilst the $p$-values (Sig) estimate the significance of the predictive effect (Pallant, 2010). The significance of the relationship is established when the $p$-value is below 0.05 .

\section{Discussion of the results}

It stands to reason that a leader with a good heart (i.e. empathy) and rational head (i.e. staff engagement) is likely to inspire enviable performance (i.e. hands) especially during times of change which customarily precipitates uncertainty, anxiety, low morale and turnover intentions amongst staff poorly management. That said, a leader's EI becomes key to unlocking and inspiring positive behavioural response if equipped to strike a good balance between head, heart and hands. From the result of this study, it is evident that the higher a manager/leader's EI, the better the chances of enhancing individual's work behaviours, resulting in improved satisfaction, commitment, performance and high morale. The results from the regression analysis in this study illuminated this inference where all constructs revealed significant positive relationship with manager/leader's EI, except for staff morale. Qureshi et al. (2013) asserted that a leader with low EI has an adverse impact on employee morale that negatively affects staff retention levels. It is imperative for the TVET management to apprehend that during difficult times and where change is unavoidable, inimitable capabilities, especially EI, of this critical human asset cannot only be relied upon, but also cultivated and enhanced for all recruited managers to sustain meaningful

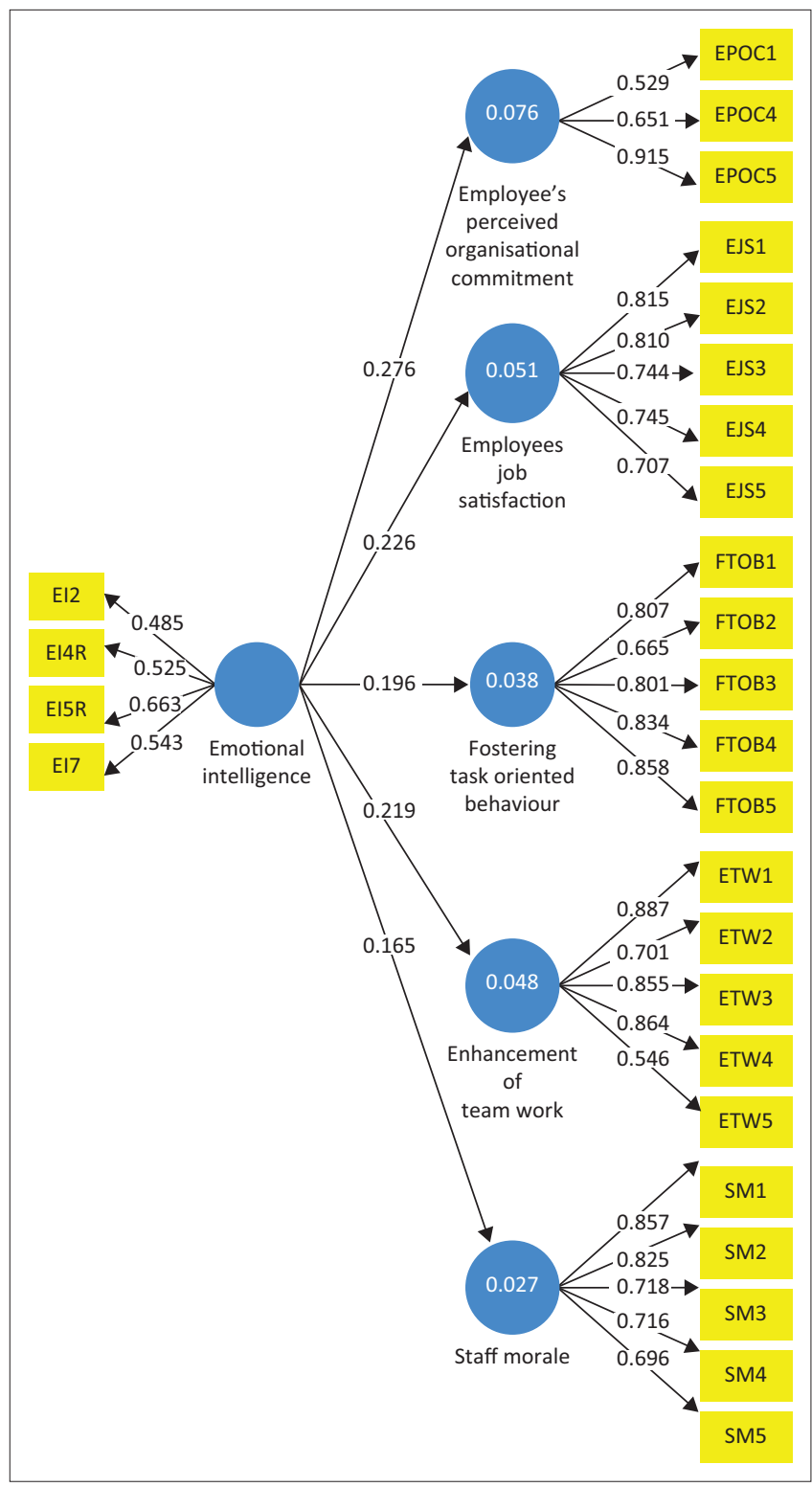

EI, Emotional intelligence; EJS, Employees job satisfaction; EPOC, Employee's perceived organisational commitment; ETW, Enhancement of team work; FTOB, Fostering task oriented behaviour; SM, Staff morale. FIGURE 2: Structural model.

TABLE 3: Fornell and Larcker (1981) matrix to assess the discriminant validity.

\begin{tabular}{|c|c|c|c|c|c|c|}
\hline Variable & Emotional intelligence & $\begin{array}{l}\text { Perceived organisational } \\
\text { commitment }\end{array}$ & $\begin{array}{l}\text { Employees job } \\
\text { satisfaction }\end{array}$ & $\begin{array}{l}\text { Enhancement of } \\
\text { teamwork }\end{array}$ & $\begin{array}{c}\text { Fostering task-oriented } \\
\text { behaviour }\end{array}$ & Staff morale \\
\hline Emotional intelligence & 0.558 & - & - & - & - & - \\
\hline $\begin{array}{l}\text { Employee's perceived } \\
\text { organisational commitment }\end{array}$ & 0.276 & 0.717 & - & - & - & - \\
\hline Employee's job satisfaction & 0.226 & 0.671 & 0.765 & - & - & - \\
\hline Enhancement of teamwork & 0.219 & 0.566 & 0.735 & 0.781 & - & - \\
\hline $\begin{array}{l}\text { Fostering task-oriented } \\
\text { behaviour }\end{array}$ & 0.196 & 0.564 & 0.759 & 0.653 & 0.796 & - \\
\hline Staff morale & 0.165 & 0.390 & 0.568 & 0.582 & 0.620 & 0.765 \\
\hline
\end{tabular}


TABLE 4: Standardised regression weights and hypothesis conclusion.

\begin{tabular}{|c|c|c|c|}
\hline Variable & Beta value & $P$ value & Conclusion \\
\hline $\begin{array}{l}\text { Emotional intelligence } \rightarrow \text { Employee's perceived } \\
\text { organisational commitment }\end{array}$ & 0.276 & 0.007 & $\begin{array}{l}\text { El has a positive }(\beta=0.276) \text { and significant }(p<0.05) \text { effect on Employee's perceived } \\
\text { organisational commitment. Meaning that when El improves by } 1 \text { standard deviation, there are } \\
95 \% \text { chances that Employee's perceived organisational commitment also goes up by } 27.6 \% \text { of } \\
\text { its own standard deviation. Therefore, this hypothesis is accepted. }\end{array}$ \\
\hline $\begin{array}{l}\text { Emotional intelligence } \rightarrow \text { Employee's job } \\
\text { satisfaction }\end{array}$ & 0.226 & 0.014 & $\begin{array}{l}\text { El has a positive }(\beta=0.226) \text { and significant }(p<0.05) \text { effect on Employee's job satisfaction. } \\
\text { Meaning that when El improves by } 1 \text { standard deviation, there are } 95 \% \text { chances that } \\
\text { Employee's job satisfaction also goes up by } 22.6 \% \text { of its own standard deviation. Therefore, this } \\
\text { hypothesis is accepted. }\end{array}$ \\
\hline $\begin{array}{l}\text { Emotional intelligence } \rightarrow \text { Enhancement of } \\
\text { teamwork }\end{array}$ & 0.219 & 0.013 & $\begin{array}{l}\text { El has a positive }(\beta=0.219) \text { and significant }(p<0.05) \text { effect on Enhancement of teamwork. } \\
\text { Meaning that when El improves by } 1 \text { standard deviation, there are } 95 \% \text { chances that } \\
\text { Enhancement of teamwork also goes up by } 21.9 \% \text { of its own standard deviation. Therefore, this } \\
\text { hypothesis is accepted. }\end{array}$ \\
\hline $\begin{array}{l}\text { Emotional intelligence } \rightarrow \text { Fostering } \\
\text { task-oriented behaviour }\end{array}$ & 0.196 & 0.033 & $\begin{array}{l}\text { El has a positive }(\beta=0.196) \text { and significant }(p<0.05) \text { effect on Fostering task-oriented } \\
\text { behaviour. Meaning that when El improves by } 1 \text { standard deviation, there are } 95 \% \text { chances that } \\
\text { Fostering task-oriented behaviour also goes up by } 19.6 \% \text { of its own standard deviation. } \\
\text { Therefore, this hypothesis is accepted. }\end{array}$ \\
\hline Emotional intelligence $\rightarrow$ Staff morale & 0.165 & 0.421 & $\begin{array}{l}\text { El has a positive }(\beta=0.165) \text { and non-significant }(p>0.05) \text { effect on Staff morale. Meaning that } \\
\text { El will not translate into an improvement of staff morale. Therefore, this hypothesis is rejected. }\end{array}$ \\
\hline
\end{tabular}

engagement and continued performance. This inference is premised on a plethora of documentary evidence indicating a positive relationship between a culture of human capital development and job satisfaction, organisational commitment (Naong, 2010; Shafiq \& Rana, 2016), task teamwork (Berber et al., 2020; Manzoor, Ullah, Hussain, \& Ahmad, 2011; Tabassi et al., 2011), task oriented (not only an investment in sustained organisational success, but also prepare and equip the workforce to be part of the solution to any future work related demands and challenges.

\section{Practical implications}

The findings presented from this study are applicable across the entire management levels of the TVET sector in South Africa. The management needs to be circumspect in their recruitment and selection of managers/leaders. Sustainable employee performance is inspired by high EI leaders because they exhibit strong interpersonal relationships, innovation and creativity as well as motivation for themselves and their subordinates. The Free State TVET top management needs to initiate actions that will develop an organisational culture conducive to employee loyalty, teamwork and improved performance. Volitional employee performance and efficiency is a factor of a leader/manager's high EI and are critical factors for driving sustainable organisational success and competitive advantage.

\section{Study limitations and recommendations}

This entire research study was conducted at four TVET colleges found in one province of South Africa. Therefore, it is not possible to generalise the findings to the entire TVET sector in the country. Additionally, the small sample size is another shortcoming. Conversely, the results paint a positive picture of the impact of managers/leaders' EI on numerous work-related behaviour variables, excluding staff morale. Drawing from these findings and the in-depth literature review, the following tactical and strategic priorities are recommended for the Free State TVET sector to ameliorate and effect an impactful 'human sensitive' trajectory:

- Ensure that the recruitment strategy ensures human capital development, especially pertaining to new managers' values regarding the 'human element' as a catalyst to entrenching teamwork, collegiality and employee engagement.

- The study advocates for EI amongst the criteria for recruitment and appointment of TVET college managers, and that it should be utilised to enhance organisational behaviours such as responsibility and team building in order to ensure job satisfaction for prospective new recruits in South African TVET college sector.

- Establish and implement a wellness programme for the staff to serve as a resource or platform to deal with any personal, group and or organisational issues with the potential to impact on staff performance.

- Craft a customised TVET workload model clearly aligning leader's performance to those of subordinates pursuant to the organisation vision and goals.

- Create a culture of collaboration and teamwork at the TVET college to ensure synergy and harmonious interpersonal relations.

- For further research, the effects of TVET manager/ leader's EI on employee's demographic variables such as the age, gender, work experience, and education level could be explored.

\section{Conclusion}

Behaviour results from emotions and perceptions, so EI is reflected in a manager/leader's behaviour (Momeni, 2009). Documented research continues to state that EI is a fundamental variable that affects leaders and their team members' performance. However, there is little evidence from this study about the effects of leaders' EI on staff morale, particularly with reference to the five variables identified above. This article's primary intention was to explore and supply empirical evidence on the influence of manager/ leader's EI on the staff morale of TVET college employees to support future research in leadership and management. We also wanted to examine the extent of association amongst the level of leaders' EI and groups by analysing the intercorrelations matrix. Evidently, the study findings revealed a significantly positive correlation between a leader's EI and individual and organisational factors such as job satisfaction, inclination towards teamwork, perceived organisational commitment, fostering task-oriented 
behaviours amongst subordinates, elements essential to boost staff morale, performance and retention.

\section{Acknowledgements Competing interests}

The authors have declared that no competing interest exists.

\section{Authors' contributions}

S.M. conducted the literature review, performed data gathering, and prepared the first draft of the article. M.N. assisted with the overall aim of the study and refining of the article, results, and conclusions.

\section{Ethical considerations}

This research was approved by the Central University of Technology, Free State, South Africa. Ethical clearance has been provided by the Faculty Research and Innovation Committee [03/05/17] in view of the CUT Research Ethics and Integrity Framework, 2016 with reference number [Management Sciences 0717].

\section{Funding information}

Funding for this study was provided by the Central University of Technology (CUT), Free State.

\section{Data availability}

Data sharing is not applicable to this article as no new data were created or analysed in this study.

\section{Disclaimer}

The views and opinions expressed in this article are those of the authors and do not necessarily reflect the official policy or position of any affiliated agency of the authors, and the publisher.

\section{References}

Abdollahi, A., Talib, M.A., Yaacob, S.N., \& Ismail, Z. (2016). Emotional Intelligence, hardiness and smoking: Protective factors among adolescents. Journal of Child \& Adolescent Substance Abuse, 25(1), 11-17. https://doi.org/10.1080/106782 8x.2013.872070

Affum-osei, E., Acquaah, E., \& Acheampong, P. (2015). Relationship between organisational commitment and demographic variables: Evidence from commercial bank in Ghana. American Journal of Industrial and Busines Management, 5(12), 769-778. https://doi.org/10.4236/ajibm.2015.512074

Ahmed, N.O.A. (2019). Career commitment: The role of self-efficacy, career satisfaction and organizational commitment. World Journal of Entrepreneurship, Management and Sustainability Development, just-accepted(just-accepted), 0000. https://doi.org/10.1108/WJEMSD-06-2017-0038

Alrowwad, A., Almajali, D., Masa'deh, R., Obeidat, B., \& Aqqad, N. (2019, April $10-11)$. The role of organizational commitment in enhancing organizational effectiveness. In Conference: Proceedings of the 33rd International Business Information Management Association Conference (pp. 9133-9154). Granada: Inform
IBIMA.

Asad-ur-Rehman, Ullah, M.I., \& Abrar-ul-haq, M. (2015). The influence of individual characteristics on organization performance and job satisfaction. International Journal of Scientific and Research Publications, 5(2), 1-6.

Ashkanasy, N.M. (2001). The case for emotional intelligence in work-groups. Symposium presentation at the annual conference of the Society for Industria and Organizational Psychology, April, San Diego, CA.

Bakotić, D. (2016). Relationship between job satisfaction and organisational performance. Economic Research-Ekonomska Istraživanja, 29(1), 118-130.
https://doi.org/10.1080/1331677X.2016.1163946
Berber, N., Slavi, A., \& Aleksi, M. (2020). Relationship between perceived teamwork effectiveness and team performance in banking sector of Serbia. Sustainability, 12(8753), 1-15. https://doi.org/10.3390/su12208753

Brown, A.T. (2015). Confirmatory Factor Analysis for Applied Research (2nd ed.). New York: The Guilford Press.

Cavallo, K., \& Brienza, D. (2002). Emotional competence and leadership excellence at Johnson and Johnson: The emotional intelligence leadership study. Retrieved from http://www.eiconsortium.org.

Clark, R., Callister, R.R., \& Wallace, R. (2002). Undergraduate management skills courses and student's emotional intelligence. Manuscript submitted for publication.

Constance, L.C., Iris, A.P., \& Colleen, A.R. (2011). Job Satisfaction and Career Commitment Among Alzheimer's Care Providers: Addressing Turnover and Improving Staff Empowerment. American Journal of Alzheimer's disease and Other Dementias, 26(7): 521-527.

Cook, C.R. (2006). Effects of emotional intelligence on principals' leadership performance. Unpublished doctoral dissertation, Doctor of Education in Education. Bozeman, MT: Montana State University.

Creswell, J.W. (2014). Research design (4th ed). Thousand Oaks, CA: Sage.

Dansereau, F. Graen, G., \& Haga, W. (1975). A vertical dyad linkage approach to leadership within formal organisation: a longitudinal investigation of the role making process. Organizational behaviour and human performance, 13(1), 46-78.

Driskell, J.E., Salas, E., \& Driskell, T. (2018). Foundations of teamwork and collaboration American Psychologist, 73, 334-348. https://doi.org/10.1037/amp0000241

Field, A. (2013). Discovering statistics using SPSS (4th ed.). London: Sage Publications Ltd.

Foltin, A., \& Keller, R. (2012). Leading change with emotional intelligence. Nursing Management, 43(11), 20-25. https://doi.org/10.1097/01.NUMA.0000421675. 33594.63

Fornell, C., \& Larcker, D.F. (1981). Evaluating structural equation models with unobserved variables and measurement error. Journal of Marketing research, 18(1), 39-50.

Gabcanova, I. (2011). The employees - The most important asset in the organisations. Human Resources Management \& Ergonomics, 5(1), 1-12.

Gaubatz, J.A., \& Ensminger, D.C. (2017). Department chairs as change agents: Leading change in resistant environments. Educational Management Administration and Leadership, 45(1), 141-163. https://doi.org/10.1177/1741143215587307

Goleman, D. (1995). Emotional Intelligence: Why It Can Matter More Than IQ. London: Bloomsbury.

Goleman, D. (2001). Emotional intelligence: Issues in paradigm building. In C. Cherniss \& D. Goleman (eds.), The emotionally intelligent workplace. How to select for measure and improve emotional intelligence in individuals, groups and organizations (pp. 13-26). San Francisco, CA: Jossey-Bass.

Goleman, D., Boyatzis, R., \& McKee, A. (2002). Primal leadership: realizing the power of emotional intelligence. Boston: Harvard Business School Press.

Gupta, R., \& Bajaj, B. (2017). The relationship between leader's emotional intelligence and employee creativity: A conceptual framework of mechanism. Procedia Computer Science, 122, 471-477. https://doi.org/10.1016/j.procs.2017.11.395

Hanafi, A. (2016). Influence of individual characteristic and organization climate on job satisfaction and its impact on employee performance. Sains Humanika, 8(4), 37-44. https://doi.org/10.11113/sh.v8n4.843

Hira, A., \& Waqas, I. (2012). A study of job satisfaction and IT's impact on the performance in the banking industry of Pakistan. International Journal of Business and Social Science, 3(19), 174-180.

Hosany, S., Prayag, G., Deesilatham, S., Cauševic, S., \& Odeh, K. (2015). Measuring tourists' emotional experiences: Further validation of the destination emotion scale. Journal of Travel Research, 54(4), 482-495.

Issah, M. (2018). Change leadership: The role of emotional intelligence. SAGE Open Research Paper, 8(3), Article first published online: September 14, 2018; Issue published: July 1, 2018. https://doi.org/10.1177/2158244018800910

Issah, M., \& Zimmerman, J.A. (2016). A change model for 21st century leaders: The essentials. International Journal of Pedagogical Innovations, 4(1), 23-29. https:// doi.org/10.12785/ijpi/040103

Khalili, A. (2012). The role of emotional intelligence in the workplace: A literature review. International Journal of Management, 29(3), 355-370.

Khanzada, B., Naeem, S., \& Butt, H. (2018). Emotional intelligence influence on employee's/organizational performance with mediating role of job satisfaction in Pakistani health sector. Journal of Health Education and Research Development, 6(2), 1-6. https://doi.org/10.4172/2380-5439.1000253

Kwateng, K.O., Osei, H.V., \& Abban, E. (2014). Organizational communication in public health institutions. International Journal of Business Management, 9(11) 179-188. https://doi.org/10.5539/ijbm.v9n11p179

Latif, M.S., Ahmad, M., Qasim, M., Mushtaq, M., Ferdoos, A., \& Naeem, H. (2015). Impact of employee's job satisfaction on organizational performance. European Journal of Business and Management, 7, 166-171.

Lazenby, J.J. (2018). The strategic management process: A South African perspective (2nd ed.). Pretoria: Van Schaik Publishers.

Lee, C., Scheunemann, J., Hall, R., \& Payne, R. (2012). Low staff morale and burnout: Causes and solutions. Champaigne: Office of Recreation and Park Resources, University of Illionois, Urbana-Champaigne.

Leedy, P.D., \& Ormrod, J.E. (2010). Practical research: Planning design (9th ed.). New Jersey: Pearson Prentice Hall. 
Mafini, C., \& Pooe, D.R.I. (2013). The relationship between employee satisfaction and organisational performance: Evidence from a South African government organisational performance: Evidence from a South African government
department. The SA Journal of Industrial Psychology, 39(1). Retrieved from http:// www.sajip.co.za/index.php/sajip/article/view/1090/1332

Malhotra, K.N., Nunan, D., \& Birks, F.D. (2017). Marketing Research: An applied approach. London: Pearson Education.

Manzoor, S.R., Ullah, H., Hussain, M., \& Ahmad, Z.M. (2011). Effect of teamwork on employee performance. International Journal of Learning and Development, 1(1) 110-126. https://doi.org/10.5296/ijld.v1i1.1110

Mayer, J.D., \& Salovey, P. (1997). What is emotional intelligence? In P. Salovey \& D. Sluyter (eds.), Emotional development and emotional intelligence: Implication for educators (pp. 3-31). New York, NY: Basic.

Milligan, I., Kendrick, A., \& Avan, G. (2004). A Survey of Job Satisfaction, Staff Morale and Qualifications in Residential Child Care in Scotland. Scottish Institute of Residential Child Care, University of Strathclyde. Retrieved from https:// pureportal.strath.ac.uk/filesasset/5584248/SET_Scotland_Staff_Morale_Report. pdf

Momeni, N. (2009). The relation between managers' emotional intelligence and the organizational climate they create. Public Personnel Management, 38(2)
35-48.

Monahan, K. (2013). What do values have to do with it? An exploration into the moderating impact of work values on the relationship between LeaderMember-Exchange and work satisfaction. Academy of Strategic Management 12(1), 95-111.

Moore, B. (2009). Emotional intelligence for school administrators: A priority for school reform? American Secondary Education, 37(3), 20-28.

Myeni, A. (2010). Leadership behaviour and employee morale within the Department of Agriculture (Submitted in accordance with the requirements for Doctor of Public Administration degree). University of South Africa.

Naong, M.N. (2010). Justification for skills transfer and validating a specific developed measuring instrument. African Journal of Business Management, 4(6) 1085-1094.

Naong, M.N. (2014). The impact of skills-development training on lower-leve employee's motivation and job satisfaction - A case-study of five South African companies. Mediterranean Journal of Social Sciences, 5(20), 369-380. https://doi. org/10.5901/mjss.2014.v5n20p369

Ngambi, H.C. (2011). The relationship between leadership and employee morale in higher education. African Journal of Business Management, 5(3), 762-776.

Ngirande, H., \& Timothy, H.T. (2014). The relationship between leaders emotional intelligence and employee job satisfaction. Mediterranean Journal of Socia Sciences, 5(9), 69. https://doi.org/10.5901/mjss.2014.v5n6p35

Nordin, N. (2011). The influence of emotional intelligence, leadership behaviour and organisational commitment for change in higher learning institutions. ProcediaSocial and Behavioral Science, 29, 129-135. Retrieved from www.sciencedirect. com

Northhouse, P.G. (2009). Leadership: Theory and Practice. Thousand Oaks, CA Sage.

Owolabi, A.B. (2012). Effect of psychological work climate and emotional intelligence on teamwork. Journal of Asian Scientific Research, 2(3), 150-158.

Owoseni, O. (2014). Emotional intelligence and perceived leadership behaviou effectiveness in organizations. Humanities and Social Science, 4(2), 262-269.

Pallant, J. (2010). SPSS Survival Manual: a step-by-step guide to data analysis using SPSS. Maidenhead: Open University Press/McGraw-Hill.

Pallant, J. (2010). SPSS Survival Manual (4th ed.). Sydney: McGraw Hill.

Pennsylvania State University World Campus (PSUWC). (2014). Lesson 12: Work and organizational commitment: Am l attached to the organization? PSYCH 484: Work attitudes and motivation. Retrieved from https://courses.worldcampus.psu.edu/ fa14/psych484/001/content/lesson12/lesson12_01.html

Petrides, K.V., \& Furnham, A. (2001). Trait emotional intelligence: Psychological investigation with reference to establish trait taxonomies. European Journal of Personality, 15(6), 425-448. https://doi.org/10.1002/per.416

Qureshi, I.A., Ali, R., Raza, H., \& Whitty, M. (2013). The impact of leader's emotional intelligence on employee commitment. An empirical study in the sports industry of Sialkot, Pakistan. Business and Management (IOSR-JBM), 17(5), 125-134.

Rahman, M.K.U., \& Haleem, F. (2018). On the relationship between emotional intelligence and job satisfaction. Middle East Journal of Business, 13(3), 13-17. https://doi.org/10.5742/MEJB.2018.93372

Ramlall, I. (2017). Applied Structural Equation Modelling for Researchers and Practitioners: Using R and Stata for Behavioural Research. Bingley: Emerald Group Publishing.
Russell, J.E.A. (2020). Leading in a time of crisis. Forbes. Retrieved from https://www. forbes.com/sites/joyceearussell/2020/07/26/leading-in-times-ofcrisis/?sh=18a63d256ed2

Salas, E., Sims, D.E., \& Burke. C.S. (2005). Is there a "big five" in teamwork? Small Group Research, 36, 555-599. https://doi.org/10.1177/1046496405277134

Salovey, P., \& Mayer, J.D. (1990). Emotional intelligence. Imagination, Cognition and Personality, 9(3), 185-211. https://doi.org/10.2190/DUGG-P24E-52WK-6CDG

Sariolghalam, N., Noruzi, M.R., \& Rahimi, G.R. (2010). The enigma of Howard Gardner's multiple intelligences theory in the area of organizational effectiveness. Business and Management, 5(5), 161-168. https://doi.org/10.5539/ijbm. v5n5p161

Schutte, N.S., Malouff, J.M., Hall, L.E., Haggerty, D.D., Cooper, J.T., Golden, C.J., \& Dornheim, L. (1998). Development and validation of a measure of emotional intelligence. Personality and Individual Differences, 25(2), 167-177. https://doi org/10.1016/S0191-8869(98)00001-4

Sekaran, U. (2003). Research methods for business: A skill-building approach (4th ed.) New York, NY: John Wiley \& Sons.

Shafiq, M., \& Rana, A.R. (2016). Relationship of emotional intelligence to organizational commitment of college teachers in Pakistan. Eurasian Journal of Educationa Research, 62, 1-14. https://doi.org/10.14689/ejer.2016.62.1

Singh, A., \& Gupta, B. (2015). Job involvement, organizational commitment, professional commitment, and team commitment. Benchmarking: An International Journal 22(6), 1192-1211. https://doi.org/10.1108/BIJ-01-2014-0007

Smith, P.C., Kendall, L.M., \& Hulin, C.L. (1969). The Measurement of Satisfaction in Work and Retirement. Chicago: Rand McNally.

Strickland, D. (2000). Emotional intelligence: The most potent factor in the success equation. Nursing Administration, 30(3), 112-117. https://doi.org/10.1097/ 00005110-200003000-00002

Švecová, S. (2009). Personálny manažment. Bratislava: Dr. Josef Raabe Slovensko.

Tabassi, A.A., Ramli, M., \& Abu Bakar, A.H. (2011). Training, motivation and teamwork improvement: The case of construction firms. African Journal of Business Management, 5(14), 5627-5636. https://doi.org/10.5897/AJBM10.1343

Taherdoost, H. (2016). Validity and Reliability of the Research Instrument; How to Test the Validation of a Questionnaire/Survey in a Research. International Journal of Academic Research in Management, 5(3), 28-36.

Tiwari, U. (2014). A study on employee morale and its impact on employee efficiency at Jaypee Cement Plant REWA (M.P.). Abhinav International Monthly Refereed Journal of Research in Management and Technology, 3(11), 8-14.

Treputtharat, S., \& Tayiam, S. (2014). School climate affecting job satisfaction of teachers in primary education, Khon Kaen, Thailand. Procedia - Social and Behavioural Science, 116, 996-1000. https://doi.org/10.1016/j.sbspro.2014.01.334

Usop, A.M., Askandar, K., Kadtong, M.L., \& Usop, D.A.S.O. (2013). Work performance and job satisfaction among teachers. International Journal of Human Social Sciences, 3(5), 245-252.

Vasudevan, H., \& Mahadi, N. (2017). Emotional intelligence, commitment and climate in organizations: Bridging contribution and practical implication. Review of Integrative Business and Economics Research, 6(1), 202-216.

Vidyarthi, P.R., Liden, R.C., Anand, S., Erdogan, B., \& Ghosh, S. (2010). Where do stand? Examining the effects of leader-member exchange social comparison on employee work behaviors. Journal of Applied Psychology, 95(5), 849. https://doi. org/10.1037/a0020033

Wijekoon, C.N., Amaratunge, H., De Silva, Y., Senanayake, S., Jayawardane, P., \& Senarath, U. (2017). Emotional intelligence and academic performance of medical undergraduates: A cross-sectional study in a selected university in Sri Lanka. BMC Medical Education, 17, 176. https://doi.org/10.1186/s12909-017 1018-9

Wisse, B., Rus, D., Keller, A.C., \& Sleebos, E. (2019). 'Fear of losing power corrupts those who wield it': The combined effects of leader fear of losing power and competitive climate on leader self-serving behaviour. European Journal of Work and Organizational Psychology, 28(6), 742-755. https://doi.org/10.1080/135943 $2 X .2019 .1635584$

Wolmarans, I.S. \& Greef, A. (2001). 360-Degree Emotional Competency Profiler Johannesburg: Learning Link International.

Yang, J. (2016). Thriving Organisational Sustainability through Innovation: Incivility Climate and Teamwork. Sustainability, 8(9), 860. https://doi.org/10.3390/ su8090860

Yukl, G. (2010). Leadership in organisations (7th ed.). Cape Town: Pearson.

Yusoff, R., Muda, T.E.A.T., \& Ishak, N.M. (2016). Relationship between emotional intelligence and job satisfaction among school counselling head teachers. Journal of Human Social Sciences, 21, 61-68. 